\title{
Evaluation of Management of Patients who Admit to Emergency Service with Dyspeptic Complaints
}

\section{Acil Servise Dispeptik Yakınmalarla Müracaat Eden Hastaların Yönetiminin Değerlendirilmesi}

\author{
-Hacı Mehmet Çalışkan', @Burak Çelik² \\ ${ }^{1}$ Kırşehir Ahi Evran ÜniversitesiTıp Fakültesi, Acil Tıp Anabilim Dalı, Kirşehir, Türkiye \\ ${ }^{2}$ Kırşehir Ahi Evran Üniversitesi Eğitim ve Araştırma Hastanesi, Acil Servisi, Kirşehir, Türkiye
}

\begin{abstract}
Aim: Dyspepsia means difficulty in the digestive process and consists of symptoms of bloating, pain, burning, early satiety, nausea and burping. Dyspepsia is one of the leading causes of admission to emergency services. Medical workups are overdone since there is still no consensus about the management of dyspeptic patients in emergency service. The aim of this article is to evaluate what is done for the management of patients with dyspeptic complaints in the emergency service.

Material and Method: This study was conducted by retrospective file scanning method and consisted of 2798 cases who admitted to the emergency service between 1 January - 31 December 2019 with dyspeptic complaints.

Results: Most of the patients included in the study were female $(58.1 \%)$ and the mean age was $39.73 \pm 17.34 .77 .8 \%$ of the included patients were treated in yellow area while $54.8 \%$ were diagnosed with gastritis. While $98.5 \%$ of the patients were discharged with outpatient treatment in the emergency observation room, only $1.5 \%$ were hospitalized. One case admitted with dyspepsia diagnostic code and presented with epigastric pain died.

Conclusion: In this study, it was found that patients with dyspeptic complaints presented to the emergency department at a very high rate and almost all patients benefited from outpatient treatment. In medical care, careful history taking and detailed physical examination of patients with dyspeptic complaints are considered important to avoid unnecessary investigations in the diagnostic process and to utilize resources appropriately as a developing country.
\end{abstract}

Keywords: Emergency service, dyspepsia, patient management, gastritis
Öz

Amaç: Dispepsi sindirim işleminin zorluğu anlamına gelip üst batında hissedilen şişkinlik, ağrı, yanma, erken doyma, bulantı ve geğirti semptomlarından oluşur. Dispepsi acil servislere başvurunun önde gelen nedenlerinden bir tanesidir. Dispeptik hastaların acil serviste yönetimi hakkında halen bir uzlaşmanın olmaması nedeni ile gereğinden fazla tetkikler yapılmaktadır. Bu makalede amaç bir acil serviste dispeptik yakınma ile başvuran hastaların yönetiminde nelerin yapıldığını incelemektir.

Gereç ve Yöntem: Bu çalışma, retrospektif dosya taraması yöntem ile yapılmış olup; 1 Ocak-31 Aralık 2019 tarihleri arasında acil servise dispeptik yakınma nedeni ile başvuran 2798 vaka üzerinde yapılmışıı. Bulgular: Çalışmaya dahil edilen hastaların çoğunluğu $(\% 58,1)$ kadın olup yaş ortalaması 39,73 $\pm 17,34$ yıldır. Dahil edilen hastaların \%77,8'i sarı alanda tedavi edilirken,\%54,8'i gastrit tanısı aldı. Hastaların \%98,5'i acil servis gözleminde günübirlik tedavi alarak taburcu olurken sadece $\% 1,5^{\prime}$ ine hastane yatışı yapılmıştır. Dispepsi tanı kodu ile kabul edilen ve epigastrik ağrı ile başvuran 1 vaka vefat etmiştir.

Sonuç: Bu çalışmada dispeptik yakınmalı hastaların acil servise çok yüksek oranda başvurduğu ve hastaların neredeyse tamamına yakınının ayaktan tedaviden fayda gördüğü tespit edilmiştir. Sağlık hizmet sunumunda dispeptik yakınmalı hastalardan alınacak dikkatli bir öykü ve ayrıntılı fizik muayene, tanı sürecinde gereksiz tetkiklerin önlenmesi ve gelişmekte olan bir ülke olarak kaynakların yerinde kullanılması açıından önemli olduğu değerlendirilmektedir.

Anahtar Kelimeler: Acil servis, dispepsi, hasta yönetimi, gastrit 


\section{INTRODUCTION}

The term dyspepsia derives from words "Dys" and "pepsis" and means difficulty in the process of digestion. Dyspepsia is not a diagnosis but a combination of symptoms which are bloating, pain, burning, early satiety, nausea and burping felt in the upper abdomen. ${ }^{[1]}$ While dyspeptic complaints may stem from an underlying organic cause (gastritis, peptic ulceration, duodenal ulceration or gastric duodenal cancers), there are dyspepsia cases (functional dyspepsia) which doesn't have any underlying organic, systemic or metabolic cause. ${ }^{[1-3]}$ Most of the dyspeptic complaints (75\%) are functional dyspepsia; and it is more common in females, smokers, non-steroid anti-inflammatory drug users and people with Helicobacter pylori infection. ${ }^{[4,5]}$

Dyspeptic complaints are very common in our country and the world during our daily life. The prevalence of dyspepsia varies from region to region, and rates varying between $\% 3$ and $\% 40$ have been reported in Europe, North America and Ocean countries. ${ }^{[6,7]}$ In a study conducted in Thailand, the public prevalence rate of dyspepsia was reported as $66 \%$. ${ }^{[8]}$ Death is not expected in dyspeptic complaints, except for complications. ${ }^{[4,9]}$ However, it is very important because it is a common disease, has a chronic process, adversely affects daily life and quality of life, and increases unjustifiable costs related to health system. ${ }^{[10-13]}$ In the United States, the annual cost of dyspepsia is more than $\$ 18$ billion. ${ }^{[4,13]}$

Emergency services are healthcare centers, which are easily accessible to receive healthcare services and provide free service to every patient with social security insurance in our country. Thus dyspeptic patients admit frequently which cause an increasing both in the workload in emergency services and unnecessary costs in health service delivery. The aim of this study is to determine whether the resources in health service provision are used in a cost-effective way by analyzing the management of patients who admitted to the emergency service with dyspeptic complaints.

\section{MATERIAL AND METHOD}

This study was conducted by retrospective file review method. The study was conducted on 2798 cases who admitted to the emergency service of a training and research hospital between 1 January - 31 December 2019 with dyspeptic complaints such as epigastric pain, bloating, early satiety, burping and for whom ICD diagnosis codes K21 (Gastro-esophageal reflux disease), K25 (Gastric ulcer), K27 (Peptic ulcer, site unspecified), K28 (Gastrojejunal ulcer), K29.0 (Acute gastritis) and K30 (Dyspepsia) codes were entered. Laboratory tests, imaging methods, diagnoses and treatments of the patients included in the study were obtained from the Hospital Information Management System (HIMS). In addition, data on whether the patients were hospitalized or not and which clinic the patients were admitted to were also included. Five different groupings were made in terms of the time of diagnosis related to dyspeptic complaints from the file scans of the patients as earlier (diagnosed before admitting to the emergency room with dyspepsia), at the time of admission, recurrent admission to the emergency room, later (After admission to the emergency room, at another date and by a gastroenterologist) and pre-diagnosis (treated with prediagnosis in the emergency department). No written informed consent was obtained from the patients due to retrospective study design. Patients over 18 years of age and whose ICD code was K21, K25, K27, K28, K29.0 and K30 were included. Those under 18 years of age and other diagnostic codes were excluded. All admissions of the patients who had more than one admissions during the study process were examined, but only the first admissions was included. A $p$ value of $<0.05$ was considered significant.

The study protocol was approved by Ahi Evran University Faculty of Medicine on 29.01.2019 with the decision number of 2019-02/29. The study was conducted in accordance with the Declaration of Helsinki.

\section{Statistical Method}

Statistical analysis of the study was performed using Statistical Package for Social Sciences version 21.0 software for Windows (IBM SPSS Statistics for Windows, Version 21.0. Armonk, NY: IBM Corp., USA). Normality assumption was tested by KolmogorovSmirnov and Shapiro-Wilk tests. Explanatory statistics of the variables are given as Mean \pm standard deviation, Median (interquartile at the $25^{\text {th }}$ and $75^{\text {th }}$ percentiles, IQR), and frequencies $\mathrm{n}(\%)$. For the univariate analyzes of variables in the study; Chi Square, Repeated Measures Analysis of Variance (RMANOVA), Friedman and Mann-Whitney $U$ tests were used according to the type of variable and state of assumptions.

\section{RESULTS}

$58.1 \%$ of the patients included in the study were women and $41.9 \%$ were men. The mean age of the patients is $39.73 \pm 17.34$ years; age distribution is between $18-85$ years. According to the triage category, most of the patients who admitted to the emergency department with dyspeptic complaints were admitted to the yellow area and received treatment with a rate of $77.8 \%$, while $54.8 \%$ patients were diagnosed with gastritis (ICD code: K29) (Table 1). $98.5 \%$ of the patients who admitted with dyspeptic complaints were discharged from the emergency room with outpatient treatment, while only $1.5 \%$ of them were hospitalized. Most of the patients hospitalized were hospitalized in the gastroenterology clinic and received medical treatment, while only 2 cases were diagnosed with appendicitis and were received emergency operation. A pregnant patient was referred to another center due to the need for Endoscopic Retrograde Cholangiopancreatography (ERCP), (Table 1). A 74-year-old patient, who was included in our study and presented with epigastric pain, was diagnosed with acute coronary syndrome and died in coronary intensive care he was hospitalized.

When diagnosis and laboratory findings of patients with dyspeptic complaints are compared; a statistically significant difference was found between the Hemoglobin $(\mathrm{Hgb})$, White blood cell (Wbc), Platelet (Plt), Glucose (Gluc), C-reactive protein (CRP), Estimated glomerular filtration rate (eGFR), 
Alanine aminotransferase (ALT), Gamma-glutamyl transferase (GGT), Bilirubin (Bil) levels among the groups of earlier, at the time of admission or recurrent admission $(p<0.01)$ (Table 2). Among patients with dyspeptic complaints, $\mathrm{Hgb}$, Plt and
eGFR values of at the time of admission group are lower than other diagnosis times. Wbc, CRP, Gluc, ALT, Aspartate aminotransferase (AST), GGT, Bilirubin and Troponin values were higher in at the time of admission group (Table 2).

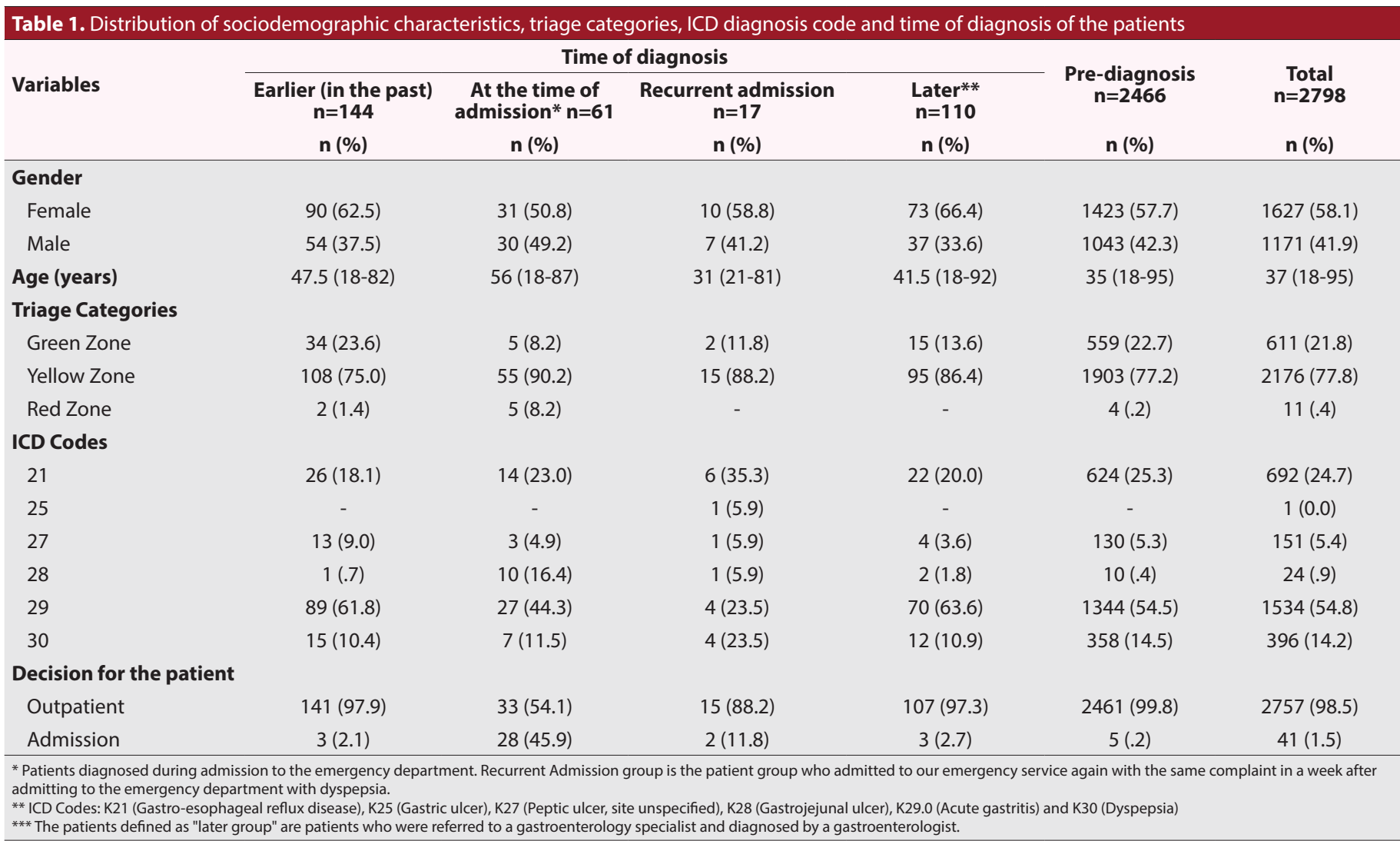

Table 2. Comparison distribution of laboratory findings and diagnosis time of patients

\begin{tabular}{|c|c|c|c|c|c|c|c|}
\hline \multirow{3}{*}{ Variables } & \multicolumn{5}{|c|}{ Time of Diagnosis } & \multirow[b]{2}{*}{$\begin{array}{l}\text { Pre-diagnosis } \\
\quad \mathrm{n}=2466\end{array}$} & \multirow{3}{*}{$\mathbf{p}$} \\
\hline & $\begin{array}{l}\text { Earlier (in the } \\
\text { past) } n=144\end{array}$ & $\begin{array}{l}\text { At the time of } \\
\text { admission* } n=61\end{array}$ & $\begin{array}{c}\text { Recurrent } \\
\text { admission } \\
n=17\end{array}$ & $\begin{array}{l}\text { Later*** } \\
n=110\end{array}$ & $\begin{array}{c}\text { Total } \\
\mathbf{n}=\mathbf{2 7 9 8}\end{array}$ & & \\
\hline & M. \pm SS & M. \pm SS & M. $\pm S S$ & M. $\pm S S$ & M. $\pm S S$ & M. \pm SS & \\
\hline \multirow[t]{2}{*}{$\mathrm{Hgb}$} & $12.8 \pm 2.2$ & $10.23 \pm 3.7$ & $13.0 \pm 1.3$ & $13.3 \pm 2.0$ & $13.7 \pm 2.2$ & $14.0 \pm 1.9$ & 0.001 \\
\hline & n (\%) & n (\%) & n (\%) & n (\%) & n (\%) & n (\%) & \\
\hline Wbc & $8.4(3.3-16.4)$ & $10.6(5.6-35.1)$ & $10.1(9.8-10.1)$ & $8.2(3.9-10.8)$ & $8.6(2.3-73)$ & $8.9(2.3-19.0)$ & 0.001 \\
\hline Plt & $285.8 \pm 83.6$ & $271.2 \pm 85.9$ & $325.6 \pm 78.9$ & $246.6 \pm 75.5$ & $270.6 \pm 82.1$ & $269.6 \pm 81.3$ & 0.001 \\
\hline Gluc & $135(75-421)$ & 140.9 (98-224) & $101.6(96-113)$ & $131.1(83-250)$ & $108(64-505)$ & $126.5(64-302)$ & 0.001 \\
\hline CRP & $0.3(0.11-0.71)$ & $0.75(0.33-2.18)$ & $0.77(0.6-1.91)$ & $0.23(0.10-0.58)$ & $0.38(0.15-0.99)$ & $0.35(0.14-0.92)$ & 0.001 \\
\hline eGFR & $86.38(42-121)$ & $76.4(9-114)$ & $127.3(120-131)$ & $83.4(34-120)$ & $95(1-153)$ & 83.8 (8.7-138) & 0.001 \\
\hline ALT & $15(5-53)$ & $24(6-184)$ & $23(11-359)$ & $18(5-101)$ & $17(5-904)$ & $16(6-96)$ & 0.001 \\
\hline AST & $22(12-43)$ & $35(12-275)$ & $21(13-549)$ & $24(12-66)$ & $21(0-549)$ & $20(6-160)$ & 0.012 \\
\hline GGT & $16.5(7-64)$ & $49(9-764)$ & $28(15-437)$ & $28(8-97)$ & $19(3-1584)$ & $19.5(5-261)$ & 0.001 \\
\hline BIL & $0.4(0.1-1.3)$ & $0.5(0.1-10.4)$ & $1.1(0.5-2.7)$ & $0.4(0.1-1.8)$ & $0.4(0-10.4)$ & $0.4(0-5)$ & 0.001 \\
\hline LIPAZ & $30.5(4-66)$ & $33(12-1362)$ & $37(16-137)$ & $37(17-60)$ & $30(3-1362)$ & $28(3-439)$ & 0.008 \\
\hline Trop & $7(0-55)$ & $9.5(0-276)$ & $3.2(3-8.9)$ & $6.2(0-44)$ & $6(0-276)$ & $5.8(0-194)$ & 0.200 \\
\hline
\end{tabular}


For the patients who admitted with dyspeptic complaints; complete blood count was requested for $24.69 \%$ ( $n=691$ ) of patients, routine biochemical test combined with CRP for $24.51 \%(n=686)$ and troponin test for $13.75 \%(n=385)$. Electrocardiography (ECG) was performed in $22.83 \%$ ( $n=639$ ) of the patients and abdominal $x$-ray (AXR) was taken in $23.73 \%$ $(n=664)$ of the cases in terms of imaging methods. In addition, 85 cases had abdominal tomography, 16 cases had endoscopy and 24 cases had abdominal ultrasonography (USG).

$\mathrm{H} 2$ receptor blocker was administered in $65.43 \%(n=1831)$, spasmolytic in $59.5 \%(n=1664)$, antiemetic in $55.78 \%(n=1561)$, and PPI (proton pump inhibitor) in $49.1 \%(n=1374)$ and liquid anti-acid in $7.46 \%(n=209)$ of patients presenting with dyspeptic complaints. Intravenous fluid therapy was initiated in $40.2 \%$ ( $n=1125)$ of the patients, and a total of $678900 \mathrm{~mL}$ fluid therapy was administered. Intramuscular treatment was applied for $25.19 \%(n=705)$ of the patients, and $27.09 \%$ $(n=758)$ of the patients were discharged with a prescription.

It was found that the majority of patients $(87.99 \%, n=2462)$ who admitted to the emergency department with dyspeptic complaints were treated with a pre-diagnosis of dyspepsia. It was found that a diagnosis related to dyspeptic complaint was made by a gastroenterologist for $5.14 \%(n=144)$ of patients before emergency service admission, $0.85 \%(n=24)$ of them during emergency service admission and in recurrent admissions and $3.93 \%(n=110)$ of them after the emergency service admission (Table 3). Of the 2798 cases presenting with dyspeptic complaints, $2.07 \%(n=58)$ of them were diagnosed with a disease in the differential diagnosis group of dyspepsia. Cholecystitis was diagnosed in 26, cholelithiasis in 12 and pancreatitis in 9 patients who admitted to emergency service with a dyspeptic complaint. Gastrointestinal system (GIS) bleeding was the most observed complication of peptic ulcer.
Also, 16 of the patients were diagnosed with GIS bleeding during their emergency admission and 2 of them during their recurrent admissions to the emergency service. 3 of the patients were diagnosed with acute coronary syndrome (ACS) and 1 of them readmitted with epigastric pain 6 hours after being discharged from the emergency room and died in the intensive care unit where (s)he was hospitalized due to cardiac arrest in the emergency department. Also, 3 of the patients who admitted with dyspepsia were diagnosed with acute appendicitis and 3 were diagnosed with pregnancy (Table 3).

Most of our patients have benefited from the treatment they received from the emergency department, only $0.6 \%$ of them $(n=17)$ were partially relieved when they were treated in the emergency service and admitted to the same emergency service again with similar complaints within the first week after their discharge from the emergency service. When these patients were reevaluated; 4 were diagnosed with cholelithiasis, 9 with cholecystitis, 1 with pancreatitis, 2 with GIS bleeding and 1 with appendicitis. Except for the case with a pre-diagnosis of dyspeptic complaint and presented with epigastric pain and diagnosed with a pre-diagnosis of ACS at the age of 74, no case died, including delayed cases (Table 3 ).

Outpatient groups and hospitalized groups of patients with dyspeptic complaints were compared in terms of age, gender, triage category and laboratory parameters (Table 4). The mean age of the patients treated by hospitalization was found to be statistically significantly higher than those treated as outpatients $(p=0.001)$. In addition, the rate of hospitalization was found to be statistically significantly higher in male patients comparing to women $(p=0.001)$. In terms of laboratory parameters, $\mathrm{Hgb}$, PIt and eGFR values were low in those who were hospitalized, while Wbc, Glucose, CRP and GGT parameters were found to be high $(p<.01)$.

Table 3. The distribution of the definite diagnoses of the patients in relation to the time of diagnosis

\begin{tabular}{|c|c|c|c|c|c|c|}
\hline \multirow{3}{*}{ Diagnosis } & \multicolumn{4}{|c|}{ Time of Diagnosis } & \multirow{3}{*}{$\begin{array}{c}\begin{array}{c}\text { Total } \\
\text { n=2798 }\end{array} \\
\text { n (\%) }\end{array}$} & \multirow{3}{*}{$\mathbf{p}$} \\
\hline & $\begin{array}{l}\text { Earlier (in the } \\
\text { past) } n=144\end{array}$ & $\begin{array}{c}\text { At the time of } \\
\text { admission* } n=61\end{array}$ & $\begin{array}{l}\text { Recurrent admission } \\
\qquad=17\end{array}$ & $\begin{array}{l}\text { Later** } \\
\mathrm{n}=110\end{array}$ & & \\
\hline & n (\%) & n (\%) & n (\%) & n (\%) & & \\
\hline Gastritis, Pangastritis & $101(49.5)$ & $3(0.01)$ & - & $100(49.0)$ & 204 & \multirow{12}{*}{0.001} \\
\hline Peptic ulcer & 34 (75.6) & $3(6.6)$ & - & $8(17.8)$ & 45 & \\
\hline GER & $4(100)$ & - & - & - & 4 & \\
\hline Cholelithiasis & $1(8.38)$ & $5(41.7)$ & $4(33.3)$ & $2(16.7)$ & 12 & \\
\hline Cholecystitis & - & $17(67.8)$ & $9(32.1)$ & - & 26 & \\
\hline Pancreatitis & - & $8(88.9)$ & $1(11.1)$ & - & 9 & \\
\hline Gastric cancer & $4(66.7)$ & - & - & $2(33.3)$ & 6 & \\
\hline GIS bleeding & - & $16(88.8)$ & $2(11.2)$ & - & 18 & \\
\hline $\mathrm{Ml}, \mathrm{ACS}$ & & $3(100)$ & & & 3 & \\
\hline Appendicitis & & $2(66.7)$ & $1(33.3)$ & & 3 & \\
\hline Pregnancy & $2(66.7)$ & $1(33.3)$ & - & - & 3 & \\
\hline Zollinger Ellison syndrome & $1(50.0)$ & - & - & - & 1 & \\
\hline
\end{tabular}




\begin{tabular}{|c|c|c|c|}
\hline Variables & $\begin{array}{c}\text { Outpatient } \\
\text { M. (Min. - Max.) }\end{array}$ & $\begin{array}{l}\text { Hospitalization } \\
\text { M. (Min. - Max.) }\end{array}$ & $\mathbf{p}$ \\
\hline \multirow[t]{2}{*}{ Age (year) } & $36(18-95)$ & $64(21-88)$ & 0.001 \\
\hline & n (\%) & n (\%) & \\
\hline \multicolumn{4}{|l|}{ Gender } \\
\hline Female & $1610(58.5)$ & 15 (36.6) & \multirow{2}{*}{0.001} \\
\hline Male & $1143(41.5)$ & $26(63.4)$ & \\
\hline \multicolumn{4}{|c|}{ Triage Category } \\
\hline Red Zone & $4(.1)$ & $7(17.1)$ & \multirow{3}{*}{0.001} \\
\hline Yellow Zone & $2140(77.7)$ & $33(80.5)$ & \\
\hline Green Zone & $609(22.1)$ & $1(2.4)$ & \\
\hline \multicolumn{4}{|c|}{ Laboratory parameters } \\
\hline HGB & $13.80(7-20)$ & $12.70(3-18)$ & 0.001 \\
\hline WBC & $8.5(7.08-10.82)$ & $9.65(7.30-13.67)$ & 0.001 \\
\hline PLT & $263(0.0-896)$ & $226(109-515)$ & 0.001 \\
\hline GLUC & $108(64-505)$ & $134(76-297)$ & 0.001 \\
\hline CRP & $0.36(0.14-0.91)$ & $0.99(0.51-2.83)$ & 0.001 \\
\hline E GFR & $96(1-153)$ & $85.5(22-137)$ & 0.005 \\
\hline ALT & $16.5(5-359)$ & $16(6-184)$ & 0.881 \\
\hline AST & $21(6-549)$ & $21(12-275)$ & 0.289 \\
\hline GGT & $20(5-437)$ & $30(9-764)$ & 0.008 \\
\hline BIL & $0.4(0.04-3.20)$ & $0.48(0.13-1.60)$ & 0.011 \\
\hline LIPASE & $28.5(9-496)$ & $32.5(4-1362)$ & 0.130 \\
\hline TROP & $6.14(0-194)$ & $11.55(0-276)$ & 0.029 \\
\hline
\end{tabular}

\section{DISCUSSION}

As a result of the data, we obtained from our study, it was determined that there were too many patient admissions related to dyspeptic complaints among emergency room admissions. It was determined that $98.5 \%$ of these patients were discharged because they benefited from outpatient treatment in the emergency department and $87.9 \%$ of these patients were treated with a pre-diagnosis and discharged without a definitive diagnosis. Since mortality is not expected in patients presenting with dyspeptic complaints, ${ }^{[4,9]}$ while symptomatic treatment is performed in emergency departments, on the other hand complications of diseases that cause dyspepsia and diseases with high mortality in the differential diagnosis group of dyspepsia are tried to be ruled out. For these reasons, workups are planned for patients in terms of urgent and high mortality diseases. In our study, it was found that there were laboratory findings that would lead to diagnosis in $1.7 \%(n=12)$ of the patients who had a hemogram test, and in $3.35 \%$ of the patients who had a routine biochemical test. As emergency department physicians, low $\mathrm{Hgb}$ in hemogram test led to diagnosis of gastrointestinal bleeding, and high ALT, AST, GGT, Lipase parameters in biochemical test led to cholecystitis and pancreatitis diagnosis. As determined in the results of our study, the use of significant and unnecessary costs in resources of healthcare is increasing for the management of patients who admit to emergency service with dyspeptic complaints. In an article previously published in the literature, diseases causing dyspeptic complaints were found to be $54 \%$ more costly than other diseases even at the stage of diagnosis. ${ }^{[14]}$

In our study, it was found that $87.9 \%$ of the patients were not diagnosed with the endoscopic method. These cases are accepted as uninvestigated cases in the literature. ${ }^{[5,15]}$ Uninvestigated cases are observed with a rate of $7-45 \%$ in the world depending on geographical location and their definition. ${ }^{[15]}$ In an earlier study conducted in the emergency department in Turkey, it was stated that only one third of the cases who admitted to the emergency department with dyspeptic complaints applied to a gastroenterology specialist. ${ }^{[16]}$ In a meta-analysis conducted by Ford et al..$^{[5]}$ the global prevalence of uninvestigated dyspepsia was found as $21 \%$. As it is understood from that study, the majority of dyspeptic cases are uninvestigated dyspepsia cases that are not established final diagnosis via endoscopic method and these cases frequently admit to emergency services or family physicians due to their complaints rather than admitting to a gastroenterology specialist.

With a good history and detailed physical examination, a differential diagnosis of many diseases such as cardiac and vascular diseases, cholecystitis, pancreatitis, acute abdomen, ileus, malignancy and gastroenteritis can be made in patients who present to the emergency department with dyspeptic complaints. If there are cases in doubt, further examinations are planned accordingly. In a previously published study in the literature, it was stated that the incidence of cholelithiasis is high in patients with dyspeptic complaints, but dyspepsia does not cause cholelithiasis. ${ }^{[17]}$ Yet in another study, ultrasonography was performed in all patients with dyspepsia and it was reported that more than half of these patients had fatty liver and $12.8 \%$ had biliary diseases. ${ }^{[18]}$ In our study, gall bladder diseases (cholelithiasis, cholecystitis) were found to be the most common accompanying disease in patients with dyspeptic complaints. Cardiac and vascular diseases are the diseases with the highest mortality in the differential diagnosis group. Cardiac diseases such as myocardial infarction and acute coronary syndrome, and vascular diseases such as aortic dissection and aneurysm should definitely be evaluated in this patient group. In our study, one of our patients died and (s)he was a patient with a diagnosis of ACS. The most important complications of dyspeptic diseases are peptic ulcer perforation and gastrointestinal bleeding, and these should definitely be evaluated in differential diagnosis. Due to disagreements in the treatment management of dyspeptic diseases and the serious economic burden on the health insurance system ${ }^{[9]}$ guidelines were published on this issue in the USA, Canada and Europe. ${ }^{[4,19]}$ In our country, there is a guide published by Ozden ${ }^{[1]}$ however, these guidelines have been prepared specifically for gastroenterology specialists. In our 
country, at least three times the number of patients presenting to a gastroenterologist with dyspeptic complaints apply to emergency services and family physicians in family health centers. ${ }^{[16]}$ However, there is no guideline that physicians of the emergency services can use for the management of these patients who admit to emergency departments. ${ }^{[20]}$ In a study conducted by Kim et al. ${ }^{[21]}$ for family physicians, it was found that raising clinical awareness about functional dyspepsia would reduce unnecessary treatments and costs.

Patients who present to the emergency department with dyspeptic complaints respond well to symptomatic liquid antacid, $\mathrm{H} 2$ receptor blocker and $\mathrm{PPI}$ treatment. Thus, it has been found that the majority of patients were discharged after an outpatient treatment in the emergency department. In two previous studies, it was stated that $\mathrm{H} 2$ receptor blocker treatment had the same effectiveness with two different intravenous PPI preparations. ${ }^{[20,22]}$ Also, in the same study, it was determined that the cost of dyspepsia treatment with PPIs is 3 times that of the $\mathrm{H} 2$ receptor blockers treatment and 11 times that of the liquid antacid's treatment. In another study conducted in the emergency department, it was reported that PPI treatment did not have additional contribution to liquid antacid treatment. ${ }^{[22]}$ However, in our study, PPI treatment was started as the first choice in many patients and the rate of PPI/ $\mathrm{H} 2$ receptor blocker use was found $75.04 \%$. Also, we found that the use of liquid antacids in the emergency department was very low in our study. Thus, it is considered that the selection of economical preparations, which have similar effectiveness in dyspepsia treatment, will reduce treatment costs in general. In diseases that cause dyspeptic complaints, usually no abnormalities are observed in laboratory findings, except for complications. Rather, laboratory tests are required for differential diagnosis and complications. Thus, as it can be understood from the results of the study, unnecessary workups in the management of dyspeptic complaints may cause a serious increase in costs. One of the results that makes this study noteworthy is that there are very few similar studies in the literature.

\section{CONCLUSION}

As a result of the data, we obtained from our study, it was determined that there were a lot of patient admissions to emergency services due to dyspeptic complaints, 98.5\% of these patients could be discharged with outpatient treatment in the emergency department and $87.9 \%$ of these patients were treated with a pre-diagnosis of dyspepsia. It is considered that taking a careful history and performing a detailed physical examination for the diagnosis of patients with dyspeptic complaints presenting to the emergency department, and cost-effective behavior in the planning of treatment and the workups for dyspeptic complications and diseases with high mortality in the differential group of dyspepsia are important for preserving the national wealth as a developing country.

\section{Limitations}

The most important limitation of our study was that the rate of patients presenting to the emergency service due to dyspeptic complaints may be lower than it actually was. The cause of this situation is usage of "Unspecified Abdominal Pain" and "Nausea with Vomiting" as ICD diagnosis code for patients who present to emergency services with dyspeptic complaints.

\section{ETHICAL DECLARATIONS}

Ethics Committee Approval: The study protocol was approved by Ahi Evran University Faculty of Medicine on 29.01.2019 with the decision number of 2019-02/29. The study was conducted in accordance with the Declaration of Helsinki.

Informed Consent: Since our article was conducted with the retrospective file screening method, the voluntary consent form was not signed by the patients.

Referee Evaluation Process: Externally peer-reviewed.

Conflict of Interest: No conflict of interest was declared by the authors.

Financial Disclosure: The authors declared that this study received no financial support.

Author Contributions: Concept: HMÇ, Design: HMÇ, Data Collection or Processing: $\mathrm{HMÇ}$ and $\mathrm{BÇ}$, Analysis or Interpretation: HMÇ. Literature Search: $\mathrm{HMÇ,} \mathrm{BÇ,} \mathrm{Writing:} \mathrm{HMÇ}$

\section{REFERENCES}

1. Ozden A. Dyspepsia. Güncel Gastroenteroloji 2012;16:272-82.

2. Brun R and Kuo B. Functional dyspepsia. Ther Adv Gastroenterol 2010; 3(3):145-64

3. Ozden A. Fonksiyonel dyspepsia. Güncel Gastroenteroloji 2012;16:283-90.

4. Moayyedi P, Lacy BE, Andrews CN, Enns RA, Howden CW, Nimish V. ACG and CAG Clinical Guideline: Management of Dyspepsia. Am J Gastroenterol 2017;112:988-1013.

5. Ford AC, Marwaha A, Sood R, Moayyedi P. Global prevalence of, and risk factors for, uninvestigated dyspepsia: a meta-analysis. Gut 2015;64(7):1049-57.

6. Turk OP, Demirel ZB. The Role of Nutrition in the Management of Dyspepsia Symptoms (Dispepsi Semptomlarının Yönetiminde Beslenmenin Rolü). Bes Diy Derg 2017;45(3):258-63.

7. Baltacı D, Kara IH, Sonmez Cl. Birinci basamakta dispepsiye yaklaşım. Turkiye Klinikleri J Fam Med-Special Topics 2015;6(4):20-7.

8. Pittayanon R, Leelakusolvong S, Vilaichone RK et al. Thailand Dyspepsia Guidelines: 2018. J Neuro gastroenterol Motil 2019;25(1):15-26.

9. Ford AC, Forman D, Bailey AG, Axon ATR, Moayyedi P. Effect of dyspepsia on survival: a longitudinal 10-year follow-up study. Am J Gastroenterol 2012;107(6):912-21.

10. Rezailashkajani M, Roshandel D, Shafaee S, Zali MR. A cost analysis of gastro-oesophageal reflux disease and dyspepsia in Iran. Dig Liver Dis 2008;40(6):412-7.

11. Duggan AE, Elliot CA, Miller P, Hawkey CJ, Logan RFA. Clinical trial: a randomized trial of early endoscopy, Helicobacter pylori testing and empirical therapy for the management of dyspepsia in primary care. Aliment Pharmacol Ther 2008;(29):55-68.

12. Masoumi SJ ,Mehrabani D, Moradi F, Zare N, Firouzi MS, Mazloom Z. The prevalence of dyspepsia symptoms and its correlation with the quality of life among Qashqai Turkish migrating nomads in Fars Province, Southern Iran. Pak J Med Sci 2015; 31(2):325-30. 
13. Koduru P, Irani M, Quigley EMM. Definition, Pathogenesis and Management of that cursed Dyspepsia. Clin Gastroenterol Hepatol 2018;16(4):467-79.

14. Mapel D, Roberts M, Overhiser A and Mason A. The Epidemiology, Diagnosis, and Cost of Dyspepsia and Helicobacter pylori Gastritis: A Case-Control Analysis in the Southwestern United States. Helicobacter 2013;18(1):54-65.

15. Mahadeva S, Goh KL. Epidemiology of functional dyspepsia: a global perspective. World J Gastroenterol 2006;12(17):2661-6.

16. Caliskan HM, Celik B, Ersoy S. Etiological evaluation of patients who present to the emergency department with dyspeptic complaints. The Turkish Journal of Academic Gastroenterology 2020;19:41-8.

17. Duman H. Fonksiyonel Dispepsi Etyopatogenezinde Etkili faktörlerin Hastalık Semptomları ile ilişkisini değerlendirme. İstanbul, Bakırköy Dr. Sadi Konuk Egitim ve Araştırma Hastanesi, Uzmanlık Tezi 2009.

18. Salihefendic N, Zildzic M, Cabric E. A New Approach to the Management of Uninvestigated Dyspepsia in Primary Care. Med Arch 2015; 69(2):133-4.

19. Gisbert JP, Calvet X, Ferrándiz J et al. Clinical practice guideline on the management of patients with dyspepsia. Update 2012. Aten Primaria 2012;44(12):727.e1-e38

20. Elicabuk H. Dispeptik ağrı tedavisinde intravenöz esomeprazol ve ranitidinin etkinliğinin karşılaştırılması: randomize, çiftkör, kontrollü çalışma. Denizli, Pamukkale Üniversitesi Tıp Fakültesi Acil Tıp Anabilim Dalı, Uzmanlık Tezi 2014.

21. Kim SE, Kim N, Lee JY et al. Prevalence and Risk Factors of Functional Dyspepsia in Health Check-up Population: A Nationwide Multicenter Prospective Study. J Neurogastroenterol Motil 2018; 24(4): 603-13.

22. Musikatavorn K, Tansangngam P, Lumlertgul S. A randomized controlled trial of adding intravenous pantoprazole to conventional treatment for the immediate relief of dyspeptic pain. Am J Emerg Med 2012;30(9):173742. 